\title{
Senescence and protein degradation in leaf segments of young winter wheat: influence of leaf age
}

\author{
Andreas Fischer and Urs Feller ${ }^{1}$ \\ Institute of Plant Physiology, University of Bern, Altenbergrain 21, CH-3013 Bern, Switzerland
}

Received 17 June 1993; Accepted 22 September 1993

\begin{abstract}
Leaf senescence in intact wheat plants can be strongly influenced by altered source/sink relations. Interactions with other plant parts are no longer possible in detached leaves and therefore differences in their senescence behaviour reflect the physiological status of the leaf before cutting. The net degradation of chlorophylls and of selected enzyme proteins (detected by SDS-PAGE and immunoblotting) was delayed in detached young leaves as compared to senescing or mature leaves excised from the same field-grown wheat plants. The physiological leaf age was therefore decisive for the velocity of artificial senescence. Net degradation rates of the enzymes investigated varied in detached leaves. The protein quantities of plastidial glutamine synthetase, phosphoribulokinase and phosphoglycolate phosphatase decreased more rapidly than those of ferredoxin-dependent glutamate synthase and nitrite reductase. Differences were also detected between two enzymes involved in the same metabolic pathway (photorespiratory carbon cycle) but located in different subcellular compartments: the plastidial enzyme phosphoglycolate phosphatase was lost more rapidly than glycolate oxidase (peroxisomal enzyme).
\end{abstract}

Key words: Detached leaves, senescence, proteolysis, leaf age, wheat.

\section{Introduction}

Steep senescence gradients can be observed in cereals on a whole plant level as well as on an individual leaf level. The leaf directly below the ear (flag leaf) is normally the last leaf to senesce in maturing wheat plants (Feller, 1990). Within an individual leaf, natural senescence starts at the tip and proceeds towards the base (Feller, 1990). Characteristic metabolic changes have been described during this phase of development. Photosynthesis and assimilatory enzymes were shown to decrease in an early phase, while respiration remained active longer (Feller and Erismann, 1978; Feller, 1990). Aminopeptidases reached high activities in expanding and mature wheat leaves and decreased during senescence, while a carboxypeptidase was found to remain active longer (Feller, 1986; Fröhlich and Feller, 1992). Endopeptidases (especially a form with a slightly alkaline $\mathrm{pH}$ optimum) were shown to reach maximal activities late during senescence (Feller, 1986; Fröhlich and Feller, 1992).

The described senescence pattern can be strongly influenced by changes in the source-sink interactions. For example, a very rapid protein and chlorophyll degradation was initiated by steam-girdling wheat flag leaves at their base (Fröhlich and Feller, 1991, 1992). Free amino groups and buffer-soluble carbohydrates accumulated in such leaves. When the phloem was interrupted below the flag leaf node, proteins and chlorophylls were degraded earlier in the flag leaf than in the second leaf from the top (Schenk and Feller, 1990).

Leaf segments are completely isolated from interactions with other plant parts. The senescence pattern may therefore be different from that of attached leaves. An accumulation of amino acids and of carbohydrates has been shown in detached leaf material (Thimann et al., 1974; Krapp et al., 1991; Peeters and van Laere, 1992). Since leaf segments are easy to handle and to incubate under controlled conditions, they have often been used to study different aspects of the senescence process (Thomas, 1978; Malik, 1983; Duggelin et al., 1988; Hilditch et al., 1989). The influence of light and of different effectors like phytohormones and amino acids on senescence of leaf segments has been extensively studied (Martin and Thimann, 1972; Shibaoka and Thimann, 1970; Weidhase et al., 1987a, b; Okada et al., 1992). However, the leaf age and the growth conditions have generally not been considered in this context. Since, in segments, interactions

\footnotetext{
' To whom correspondence should be addressed. Fax: +41313322059.
} 
on the whole plant level are no longer possible, differences in the senescence behaviour can be related to the physiological status of the leaves prior to cutting. In the experiments reported here, detached leaves of different age cut from young, vegetative, field-grown winter wheat plants were analysed with respect to artificial senescence under controlled conditions.

\section{Materials and methods}

\section{Plant material}

Winter wheat plants (Triticum aestivum L. cv. Arina) were grown in a field near Bern. Whole shoots were collected after the restart of rapid growth in Spring 1991 (on 27 March and 10 April) and transported to the laboratory on ice. Leaf laminae were separated from the rest of the shoots and extracted immediately. For incubation experiments with leaves and leaf segments, the plants were harvested and were transported to the laboratory with their root systems standing in deionized water.

\section{Incubation of detached leaves}

Whole leaf laminae were cut into segments of approximately $4 \mathrm{~cm}$ length and incubated for $24 \mathrm{~h}$ in a culture room (13 h light, $100 \mu \mathrm{E} \mathrm{m}^{-2} \mathrm{~s}^{-1} / 10 \mathrm{~h}$ darkness $/ 1 \mathrm{~h}$ light, $21-25^{\circ} \mathrm{C}$ ). The segments were floated on a feeding solution in Petri dishes. The feeding solution consisted of $100 \mathrm{mmol} \mathrm{m} \mathrm{m}^{-3}$ methionine containing $0.1 \mu \mathrm{Ci} \mathrm{cm}^{-3}{ }^{35} \mathrm{~S}$-methionine in order to label newly synthesized proteins. In addition, intact leaf laminae standing with the cut xylem in test tubes containing the feeding solution were incubated under the same light and temperature conditions.

\section{Extraction}

The extraction medium contained $20 \mathrm{~mol} \mathrm{~m}^{-3}$ sodium phosphate buffer $\mathrm{pH} 7.5,1 \%(\mathrm{w} / \mathrm{v})$ polyvinylpolypyrrolidone and $0.1 \%(\mathrm{v} / \mathrm{v}) \beta$-mercaptoethanol. Fifteen freshly harvested leaf laminae were extracted in $9 \mathrm{~cm}^{3}$ extraction medium for older leaves (laminae 1 to 3 ) or $18 \mathrm{~cm}^{3}$ for the larger upper leaves (laminae 4 to 7 ) with a Polytron mixer (Kinematica, Littau/Luzern) for $20 \mathrm{~s}$ at medium and for $5 \mathrm{~s}$ at full speed. Three laminae incubated for $24 \mathrm{~h}$ or segments from three laminae incubated for $24 \mathrm{~h}$ were homogenized in $2 \mathrm{~cm}^{3}$ extraction medium. The crude extracts were filtered through Miracloth (Calbiochem, San Diego).

\section{Quantification of proteins and chlorophylls}

The Miracloth filtrate was mixed with acetone (final concentration $80 \%$ ) and centrifuged ( $5 \mathrm{~min}$ at $2300 \mathrm{~g}$ ) before photometry at 649 and $665 \mathrm{~nm}$. Chlorophyll was calculated according to Strain et al. (1971). Total proteins in the Miracloth filtrate were determined according to Bradford (1976) using bovine gamma globulin as the standard.

\section{Activities of peptide hydrolases}

Freshly prepared extracts were centrifuged for $10 \mathrm{~min}$ at $2300 \mathrm{~g}$. Aminopeptidases were detected in micro-titration plates using the method described previously (Blattler and Feller, 1988). L-amino acid-p-nitroanilides (final concentration in the substrate

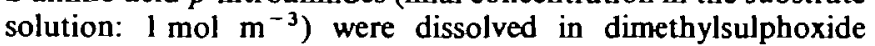
(final concentration: $2 \% \mathrm{v} / \mathrm{v}$ ) and then mixed with buffer $\left(100 \mathrm{~mol} \mathrm{~m}^{-3}\right.$ bis-tris propane and $50 \mathrm{~mol} \mathrm{~m}^{-3}$ sodium acetate adjusted to the desired $\mathrm{pH}$ value with $\mathrm{HCl}$ ). Hydrolysis of the different substrates was measured at slightly different $\mathrm{pH}$ values, according to the optima determined in a preliminary experiment. Carboxypeptidase activity was detected in micro-titration plates according to Salgó and Feller (1987) using the $N$-masked dipeptide $N$-carbobenzoxy-L-phenylalanine-L-alanine as substrate. Endopeptidase activities were analysed according to Fröhlich and Feller (1992) using azocasein as substrate. The extracts were desalted as reported previously (Feller et al, 1977) by centrifugation through Sephadex G-25 equilibrated with $20 \mathrm{~mol} \mathrm{~m} \mathrm{~m}^{-3}$ sodium phosphate buffer pH 7.5 and $0.1 \%$ (v/v) $\beta$-mercaptoethanol. The eluate $\left(400 \mathrm{~mm}^{3}\right)$ was mixed with $400 \mathrm{~mm}^{3}$ substrate solution $\left(1 \%\right.$ azocasein in $200 \mathrm{~mol} \mathrm{~m} \mathrm{~m}^{-3}$ acetate buffer $\mathrm{pH} 5.0,200 \mathrm{~mol} \mathrm{~m}^{-3}$ imidazole buffer $\mathrm{pH} 7.5$ or $200 \mathrm{~mol} \mathrm{~m}^{-3}$ bis-tris propane buffer $\mathrm{pH} \mathrm{9.0)} \mathrm{and} \mathrm{incubated} \mathrm{for}$ $3 \mathrm{~h}$ at $37^{\circ} \mathrm{C}$. Trichloroacetic acid-soluble products were determined photometrically (Frohlich and Feller, 1992).

\section{SDS-PAGE and immunoblotting}

Samples were prepared from the Miracloth filtrate and separated by sodium dodecyl sulphate polyacrylamide gel electrophoresis (SDS-PAGE) in a Mini Protean II Dual Slab Cell (BIORAD, Richmond) according to Laemmli (1970). For visualization of total proteins gels were stained with Coomassie Brilliant Blue R-250. Immunoblotting was performed according to Tijssen (1985) as described by Fröhlich and Feller (1991). All primary antibodies used were developed in rabbit. Glutamine synthetase was detected with an antibody directed against the plastidial isoenzyme from mustard (Hopfner et al., 1988). Phosphoribulokinase (Crafts-Brandner et al., 1990), nitrite reductase (Ida, 1987), ferredoxin-dependent glutamate synthase (Marquez et al, 1988), phosphoglycolate phosphatase (Baldy et al., 1989) and glycolate oxidase (Mitsuhashi and Feller, 1992) were identified on immunoblots with specific antibodies. The bands were visualized with goat-anti-rabbit-IgG for bridging and peroxidase-anti-peroxidase soluble complex (Mitsuhashi and Feller, 1992). The peroxidase substrate was 4-chloro-1-naphthol. The whole protocol from the primary antibodies to the colour reaction was repeated for the detection of nitrite reductase, phosphoglycolate phosphatase and glycolate oxidase in order to amplify the bands.

\section{Fluorography}

In order to detect the incorporation of ${ }^{35} \mathrm{~S}$-methionine into proteins during the incubation of leaf segments, the extracted proteins were separated by SDS-PAGE as mentioned above. The gels were slightly stained with Coomassie Brilliant Blue, treated with $\mathrm{EN}^{3} \mathrm{HANCE}$ (DuPont, Boston) and exposed to a preflashed X-ray film (Fuji RX) at $-80^{\circ} \mathrm{C}$ (Laskey, 1984).

\section{Results}

The four oldest leaves were senescing or starting to senesce between 27 March and 10 April, as judged by changes in protein and chlorophyll levels (Table 1 ). A considerable net decrease of various proteins (such as ribulose-1,5-bisphosphate carboxylase/oxygenase, Rubisco) was detected in these leaves on Coomassie Bluestained SDS-PAGE gels (Fig. 1). Net protein losses were between $30 \%$ and $50 \%$ during this period (Table 1 ). The fifth leaf was still growing and two additional leaves were formed. The lamina of the seventh leaf was just emerging on 10 April and was quite unequally developed in different 
Table 1. Protein and chlorophyll degradation during the incubation of detached leaves

Protein and chlorophyll contents were determined in leaf laminae from control plants freshly harvested on 27 March or on 10 April (Cont) and in leaf laminae incubated for $1 \mathrm{~d}$ in a culture room. The leaf blades were incubated either standing intact in test tubes (Incl) or floating as segments in Petri dishes (Inc2). Leaves 6 and 7 were not yet expanded on 27 March. The values for controls were calculated from four independent samples (each containing 15 leaf laminae), and the values for the incubations were determined from one sample (containing three leaf laminae).

\begin{tabular}{|c|c|c|c|c|c|c|c|c|c|c|}
\hline \multirow{3}{*}{$\begin{array}{l}\text { Leaf } \\
\text { number }\end{array}$} & \multicolumn{5}{|c|}{ Protein content (mg leaf lamina ${ }^{-1}$ ) } & \multicolumn{5}{|c|}{ Chlorophyll content ( $\mu \mathrm{g}$ leaf lamina $\left.{ }^{-1}\right)$} \\
\hline & \multicolumn{2}{|c|}{27 March } & \multicolumn{3}{|c|}{10 April } & \multicolumn{2}{|c|}{27 March } & \multicolumn{3}{|c|}{10 April } \\
\hline & Cont & Incl & Cont & Incl & Inc2 & Cont & Incl & Cont & Incl & Inc2 \\
\hline 1 & 3.1 & 2.0 & 1.5 & 0.9 & 1.0 & 59 & 47 & 40 & 22 & 27 \\
\hline 2 & 3.3 & 1.7 & 2.2 & 1.1 & 1.0 & 59 & 36 & 56 & 39 & 29 \\
\hline 3 & 5.1 & 3.1 & 3.0 & 1.4 & 1.3 & 107 & 78 & 91 & 49 & 50 \\
\hline 4 & 11.6 & 7.1 & 8.5 & 3.9 & 3.9 & 231 & 202 & 224 & 135 & 139 \\
\hline 5 & 11.9 & 9.1 & 13.0 & 7.2 & 6.8 & 169 & 215 & 320 & 266 & 230 \\
\hline 6 & & & 27.0 & 20.5 & 21.6 & & & 445 & 477 & 477 \\
\hline 7 & & & 7.4 & 3.4 & 5.9 & & & 123 & 72 & 190 \\
\hline
\end{tabular}

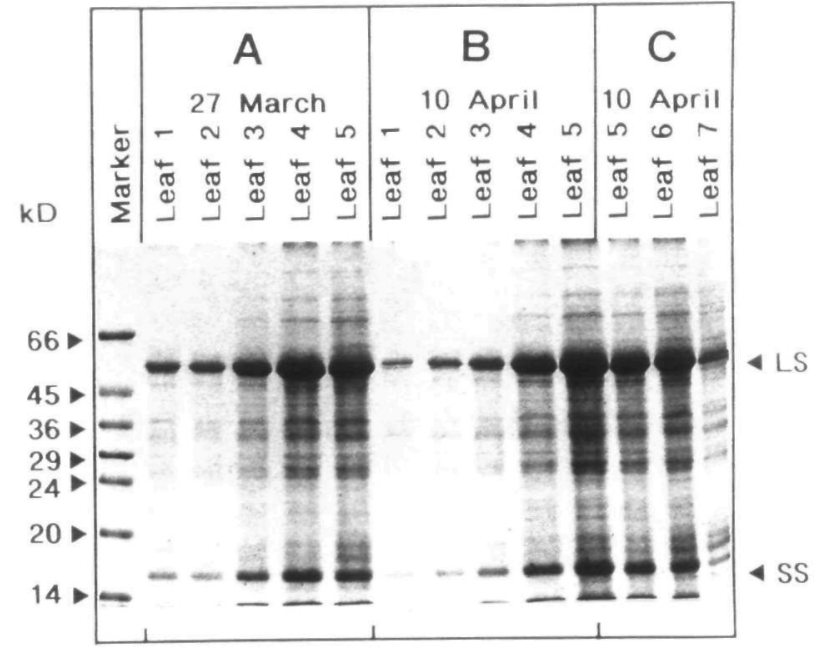

Fig. 1. Protein pattern in freshly collected leaves of different age. Leaf laminae were analysed on 27 March and on 10 April by SDS-PAGE and staining with Coomassie Brilliant Blue R-250. Each lane was loaded with a sample equivalent to $0.250 \%(\mathrm{~A}, \mathrm{~B})$ or $0.135 \%$ (C) of a leaf blade. Leaves 6 and 7 were not yet expanded on 27 March, while senescence was already initiated in leaf 1 (oldest leaf). Molecular weight markers are shown on the left side, while the large (LS) and small (SS) subunits of Rubisco are indicated on the right side.

plants. The main endopeptidase activity was detected at pH 5.0 (Table 2). The activities detected in the alkaline $\mathrm{pH}$ range are low. They may therefore represent the tail of the $\mathrm{pH}$ response curve of the major endopeptidase(s) with a $\mathrm{pH}$ optimum around 5 , and are not necessarily due to a different endopeptidase form with a high $\mathrm{pH}$ optimum which has been detected in senescing flag leaves (Feller and Keist, 1986). The endopeptidase activity found in leaf 1 on 27 March was about $200 \%$ of the activity present in whole shoots (with three leaves) a few weeks before (Fischer and Feller, 1993). For the comparison of enzyme activities in different leaves it must be borne in mind that the lowest leaves ( 1 to 3 ) were smaller than the upper leaves, as indicated by protein and chlorophyll contents (Table 1). Taking this fact into consideration, it becomes evident that endopeptidase activity was high in old leaves and remained low in expanding leaves (Table 2). Aminopeptidase activities reached high levels before endopeptidase activities in the course of leaf development (Tables 2,3 ). Only minor variations were detected between aminopeptidase activities measured with different substrates (Table 3). Several aminopeptidase forms differing in their substrate specificities have been identified in various plants (Feller, 1986; Blăttler and Feller, 1988). However, one aminopeptidase form may hydrolyse a series of substrates with different rates (Blättler and Feller, 1988, and references therein). It remains open how many aminopeptidase forms contributed to the hydrolysis of the substrates listed in Table 3.

The changes detected in detached leaves incubated for only $24 \mathrm{~h}$ in a culture room were much more rapid than the changes in the field plants (Table 1). Net protein and chlorophyll losses were quite comparable between whole leaf laminae standing with the cut xylem in test tubes and leaf segments floating on the solution in Petri dishes (Table 1). Proteins and chlorophylls were rapidly degraded when the incubated material was taken from senescing and mature leaves (leaves $1-4$ on 27 March, leaves 1-5 on 10 April), but they decreased much more slowly when the incubated material was cut from young leaves (leaf 5 on 27 March, leaves 6 and 7 on 10 April). The large variations visible for leaf 7 are due to the unequal development of this not yet fully expanded leaf at the time of excision.

The differences in net degradation between leaves of different physiological age were visible for all enzymes identified by SDS-PAGE (Rubisco) or by immunoblotting with specific antibodies (Figs 2, 3). All these enzyme proteins were much more stable in young leaves. The enzymes examined by immunoblotting were phosphoribu- 
Table 2. Endopeptidase activities in leaf laminae collected in the field on 27 March or on 10 April At the first sampling date senescence was already initiated in the oldest leaf (leaf 1), while leaf 7 was not yet expanded. Azocasein solutions buffered at three different $\mathrm{pH}$ values were used as substrates. Means and standard deviations of four independent samples (each containing 15 leaf laminae) are shown.

\begin{tabular}{|c|c|c|c|c|c|c|c|}
\hline \multirow[t]{3}{*}{$\mathrm{pH}$} & \multicolumn{7}{|c|}{ Endopeptidase activity ( $\mu \mathrm{g}$ leaf lamina ${ }^{-1} \mathrm{~h}^{-1}$ ) } \\
\hline & \multicolumn{3}{|c|}{27 March } & \multicolumn{4}{|l|}{10 April } \\
\hline & Leaf 1 & Leaf 3 & Leaf 5 & Leaf 1 & Leaf 3 & Leaf 5 & Leaf 7 \\
\hline $\begin{array}{l}5.0 \\
7.5 \\
9.0\end{array}$ & $\begin{array}{c}212 \pm 8 \\
71 \pm 13 \\
34 \pm 16\end{array}$ & $\begin{array}{c}150 \pm 17 \\
39 \pm 4 \\
8 \pm 5\end{array}$ & $\begin{array}{r}113 \pm 9 \\
46 \pm 3 \\
11 \pm 4\end{array}$ & $\begin{array}{r}186 \pm 7 \\
56 \pm 9 \\
21 \pm 5\end{array}$ & $\begin{array}{c}192 \pm 13 \\
48 \pm 23 \\
7 \pm 1\end{array}$ & $\begin{array}{c}317 \pm 26 \\
79 \pm 18 \\
15 \pm 2\end{array}$ & $\begin{array}{l}94 \pm 37 \\
33 \pm 8 \\
12 \pm 4\end{array}$ \\
\hline
\end{tabular}

Table 3. Exopeptidase activities in leaf laminae collected in the field on 27 March or on 10 April

At the first sampling date senescence was already initiated in the oldest leaf (leaf 1), while leaf 7 was not yet expanded. Carboxypeptidase (CP) was measured using an $\mathrm{N}$-masked dipeptide as substrate, and aminopeptidases (AP) were detected using $p$-nitroanilides of the amino acids indicated. Means and standard deviations of four independent samples (each containing 15 leaf laminae) are shown.

\begin{tabular}{lllll}
\hline \multirow{2}{*}{$\begin{array}{l}\text { Peptide } \\
\text { hydrolase }\end{array}$} & \multicolumn{4}{l}{ Enzyme activity (nkat leaf lamina ${ }^{-1}$ ) } \\
\cline { 2 - 5 } & Leaf 1 & Leaf 3 & Leaf 5 & Leaf 7 \\
\hline 27 March & & & & \\
CP & $5.36 \pm 0.72$ & $5.71 \pm 0.90$ & $6.02 \pm 1.34$ & \\
Ala-AP & $0.93 \pm 0.05$ & $1.49 \pm 0.11$ & $3.21 \pm 0.22$ & \\
Gly-AP & $0.13 \pm 0.01$ & $0.23 \pm 0.03$ & $0.50 \pm 0.01$ & \\
Lys-AP & $0.82 \pm 0.05$ & $1.40 \pm 0.14$ & $2.35 \pm 0.21$ & \\
Leu-AP & $0.74 \pm 0.06$ & $1.21 \pm 0.09$ & $2.31 \pm 0.18$ & \\
Met-AP & $0.38 \pm 0.02$ & $0.60 \pm 0.04$ & $1.14 \pm 0.07$ & \\
Pro-AP & $0.17 \pm 0.01$ & $0.18 \pm 0.01$ & $0.26 \pm 0.01$ & \\
Phe-AP & $0.30 \pm 0.06$ & $0.43 \pm 0.07$ & $0.47 \pm 0.01$ & \\
& & & & \\
10 April & & & & \\
CP & $4.76 \pm 0.77$ & $6.14 \pm 0.38$ & $12.86 \pm 1.42$ & $2.69 \pm 0.79$ \\
Ala-AP & $0.68 \pm 0.05$ & $1.26 \pm 0.06$ & $4.67 \pm 0.15$ & $2.48 \pm 0.56$ \\
Gly-AP & $0.17 \pm 0.03$ & $0.21 \pm 0.01$ & $0.81 \pm 0.10$ & $0.56 \pm 0.15$ \\
Lys-AP & $0.54 \pm 0.04$ & $1.00 \pm 0.03$ & $3.54 \pm 0.15$ & $1.71 \pm 0.39$ \\
Leu-AP & $0.47 \pm 0.04$ & $0.89 \pm 0.02$ & $3.05 \pm 0.12$ & $1.76 \pm 0.43$ \\
Met-AP & $0.27 \pm 0.03$ & $0.45 \pm 0.02$ & $1.56 \pm 0.15$ & $1.14 \pm 0.28$ \\
Pro-AP & $0.14 \pm 0.02$ & $0.17 \pm 0.01$ & $0.46 \pm 0.17$ & $0.64 \pm 0.16$ \\
Phe-AP & $0.33 \pm 0.12$ & $0.47 \pm 0.04$ & $0.75 \pm 0.10$ & $0.50 \pm 0.11$ \\
\hline
\end{tabular}

lokinase (another important Calvin cycle enzyme besides Rubisco); nitrite reductase (a stromal enzyme, essential for the assimilation of inorganic nitrate); glutamine synthetase and ferredoxin-dependent glutamate synthase (stromal enzymes involved in the assimilation of inorganic nitrate and in the re-assimilation of ammonia liberated by glycine decarboxylase in photorespiration); phosphoglycolate phosphatase (stromal enzyme involved in the photorespiratory carbon cycle) and glycolate oxidase (peroxisomal enzyme, also involved in the photorespiratory carbon cycle). Differences in the net degradation of these enzymes were detected in leaves 4 and 5: The protein quantities of glutamine synthetase, phosphoribulokinase and phosphoglycolate phosphatase decreased more rapidly than those of glutamate synthase and nitrite reductase (Fig. 3). Thus, the net degradation of enzymes present in the same subcellular compartment (chloroplast)

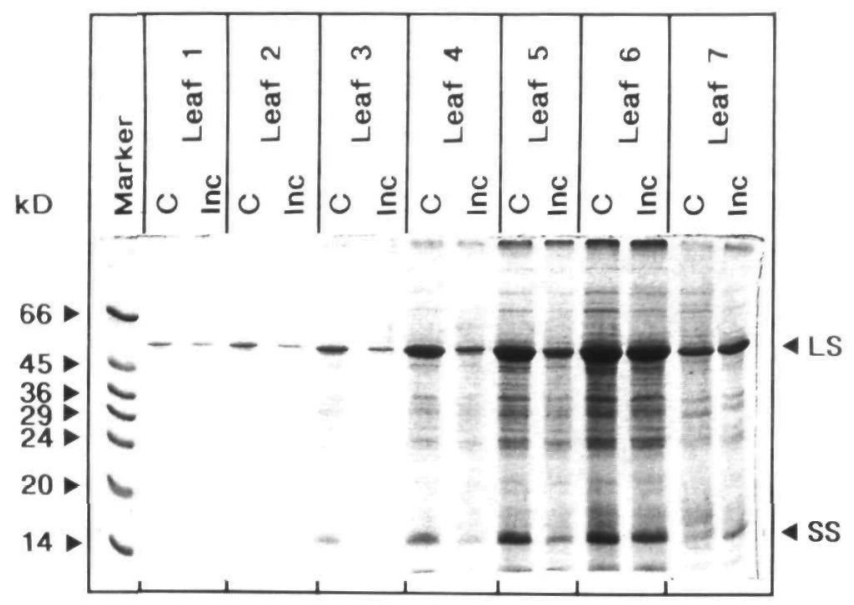

Fig. 2. Changes in the protein pattern during incubation of detached leaves. Laminae were collected in the field on 10 April, cut into segments and incubated in Petri dishes for $1 \mathrm{~d}(13 \mathrm{~h}$ light, $10 \mathrm{~h}$ dark, $1 \mathrm{~h}$ light). Freshly harvested (C) and incubated (Inc) leaves were analysed by SDS-PAGE and staining with Coomassie Brilliant Blue R-250. Each lane was loaded with a sample equivalent to $0.135 \%$ of a leaf blade. Molecular weight markers are shown on the left side, while the large (LS) and small (SS) subunits of Rubisco are indicated on the right side.

was different. Since phosphoglycolate phosphatase (plastidial enzyme) was lost more rapidly than glycolate oxidase (peroxisomal enzyme), there were also differences between enzymes involved in the same metabolic pathway (photorespiratory carbon cycle) but located in different subcellular compartments.

Protein synthesis was detected in leaf segments by the incorporation of ${ }^{35} \mathrm{~S}$-methionine (Fig. 4). It was high in the youngest leaves (leaves 6 and 7) and low in mature and senescing leaves. Consequently, the fact that net protein degradation was low in segments cut from young leaves may be due, in part, to protein synthesis still going on in these leaves. The incorporation of radioactivity into leaf proteins was always very low when intact leaf blades were fed through the cut xylem. Possibly methionine was removed from the transpiration stream before reaching the mesophyll cells. A xylem-to-phloem transfer has been shown to be important for several amino acids (Feller and Hölzer, 1991). 


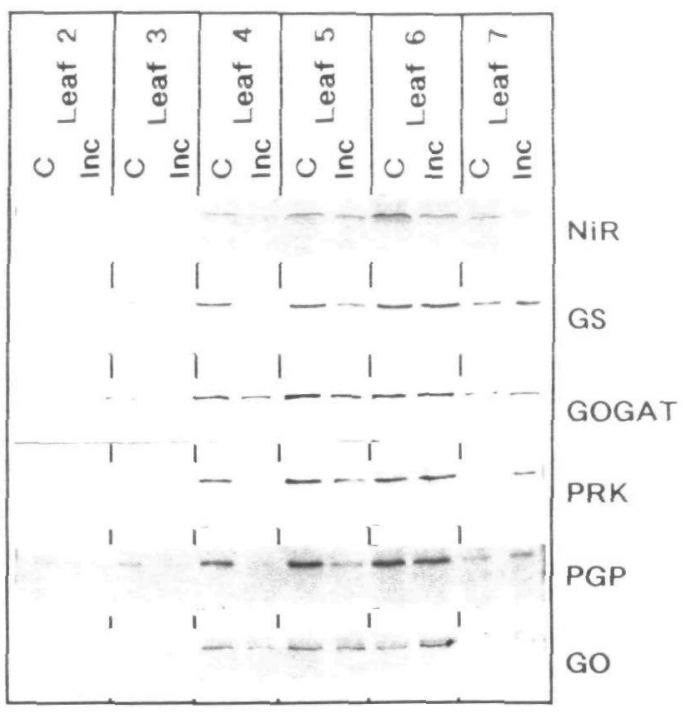

Fig. 3. Changes in the amount of selected enzyme proteins in leaves of different age. Leaves were collected in the field on 10 April. Leaf 1 (oldest leaf) was omitted since the quantities of the enzymes investigated were already below the detection limit before incubation. Detached laminae were cut into segments, incubated in Petri dishes for $1 \mathrm{~d}(13 \mathrm{~h}$ light, $10 \mathrm{~h}$ dark, $1 \mathrm{~h}$ light), and analysed by SDS-PAGE and immunoblotting. Samples equivalent to the same percentage of a leaf blade $(0.250 \%)$ were loaded on each lane. Protein quantities were analysed in freshly harvested (C) and in incubated (Inc) leaves with specific antibodies against nitrite reductase (NiR), plastidial glutamine synthetase (GS), ferredoxin-dependent glutamate synthase (GOGAT), phosphoribulokinase (PRK), phosphoglycolate phosphatase (PGP) and glycolate oxidase (GO).

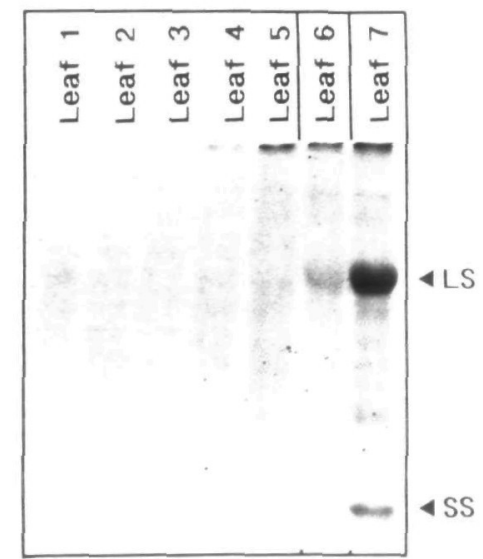

Fig. 4. Incorporation of ${ }^{35} \mathrm{~S}$-methionine into proteins in leaves of different age. Lanes 1 (oldest leaf) to 7 (youngest leaf) were collected in the field on 10 April. The laminae were cut into segments, incubated in Petri dishes with labelling solution for $1 \mathrm{~d}(13 \mathrm{~h} \mathrm{light,} 10 \mathrm{~h}$ darkness, $1 \mathrm{~h}$ light) and analysed by SDS-PAGE followed by fluorography. Each lane was loaded with a sample equivalent to $1.22 \%$ of a lamina for leaves 1 to 5 and 7 , but only $0.41 \%$ of a lamina could be loaded for leaf 6 (largest leaf). The large (LS) and the small (SS) subunits of Rubisco are indicated on the right side.

\section{Discussion}

Leaf senescence (as judged by protein and chlorophyll degradation and the activities of some peptide hydrolases) in young, vegetatively growing wheat was, in general, similar to the senescence of flag leaves during the period of grain filling (Fröhlich and Feller, 1991, 1992). A major difference was detected in the endopeptidase pattern. The main activity detected in this study was always below $\mathrm{pH} \mathrm{7,} \mathrm{although} \mathrm{it} \mathrm{was} \mathrm{reported} \mathrm{that} \mathrm{an} \mathrm{endopeptidase}$ form with a high $\mathrm{pH}$ optimum becomes more active during later phases of leaf senescence in maturing wheat plants (Feller and Keist, 1986; Fröhlich and Feller, 1992). The significance of the altered endopeptidase pattern for protein degradation is not yet clear.

Differences in the net degradation of stromal enzyme proteins were found in incubated leaf segments. It is still open to discussion how the degradation of various proteins in the same subcellular compartment with its given set of proteolytic activities can be selectively regulated. The activities of peptide hydrolases and the susceptibilities of their potential substrate proteins may be influenced by solutes (Kurlandsky et al., 1988; Feller, 1990; Fischer et al., 1992). An exchange of nutrients and assimilates with other plant parts is no longer possible in leaf segments. This may indirectly affect the exchange of solutes between the stroma and the cytosol and, as a consequence, proteolytic processes inside the chloroplasts. Different degradation rates of nuclear-encoded stromal proteins were found in isolated intact pea chloroplasts where de novo synthesis was no longer possible (Mitsuhashi and Feller, 1992). It was also shown in this system that the degradation of plastidial proteins can be influenced by solutes in the incubation medium of the chloroplasts (Mitsuhashi and Feller, 1992).

A strong influence of the physiological leaf age on net protein and chlorophyll degradation was detected in detached leaves. These differences became obvious although interactions with other plant parts were interrupted for segments from young leaves as well as for segments from mature and senescing leaves. Leaf age was important for the degradation of all investigated enzyme proteins, regardless of the differences observed between them. A redistribution of limiting phloem-mobile nutrients to young leaves (sinks) prior to cutting may be important in this context. Preliminary experiments suggest that the nutritional status of the intact plant can influence the behaviour of leaf segments during artificial senescence. Further investigations considering several environmental factors (light, temperature, nutrients) during growth of the experimental plants may allow a deeper insight into the regulatory network in senescing wheat leaf segments.

\section{Acknowledgements}

The authors thank the Landwirtschaftliche Schule Rutti in Zollikofen for supplying the plant material, Dr M. Höpfner, G. Ochs and Professor A. Wild (Johannes-GutenbergUniversităt, Mainz) for the antiserum against glutamine synthe- 
tase, Professor S.J. Crafts-Brandner (University of Kentucky, Lexington) for the antibodies against phosphoribulokinase, Professor S. Ida (Research Institute for Food Science, Kyoto) for the antibodies against nitrite reductase, Dr R.M. Wallsgrove (AFRC Institute of Arable Crops Research, Rothamsted Experimental Station, Harpenden) for the antibodies against glutamate synthase, Dr P. Baldy (Université Paul Sabatier, Toulouse) for the antibodies against phosphoglycolate phosphatase and Dr A. Fleming for improving the English of the manuscript. The work was supported by the Swiss National Science Foundation (Project 31-30805.91).

\section{References}

Baldy P, Piquemal M, Cavalie G. 1989. Phosphoglycolate phosphatase: Immunological comparisons of the enzyme from the different photosynthetic groups of plants using maize polyclonal antiserum. Plant Science 60, 9-20.

Blattler R, Feller U. 1988. Identification and stability of aminopeptidases in extracts from bean seeds. Australian Journal of Plant Physiology 15, 613-19.

Bradford MM. 1976. A rapid and sensitive method for the quantitation of microgram quantities of protein using the principle of protein dye binding. Analytical Biochemistry 72, 248-54.

Crafts-Brandner SJ, Salvucci ME, Egli DB. 1990. Changes in ribulose bisphosphate carboxylase/oxygenase and ribulose 5 -phosphate kinase abundances and photosynthetic capacity during leaf senescence. Photosynthesis Research 23, 223-30.

Duggelin T, Schellenberg M, Bortlik K, Matile P. 1988. Vacuolar location of lipofuscin- and prolin-like compounds in senescent barley leaves. Journal of Plant Physiology 133, 492-7.

Feller U. 1986. Proteolytic enzymes in relation to leaf senescence. In: Dalling MJ, ed. Plant proteolytic enzymes, Vol. II. Boca Raton: CRC Press Inc., 49-68.

Feller U. 1990. Nitrogen remobilization and protein degradation during senescence. In: Abrol YP, ed. Nitrogen in higher plants. Somerset: Research Studies Press Ltd., 195-222.

Feller U, Erismann KH. 1978. Verănderungen des Gaswechsels und der Aktivităten proteolytischer Enzyme wăhrend der Seneszenz von Weizenblăttern (Triticum aestivum L.). Zeitschrift für Pflanzenphysiologie 90, 235-44.

Feller U, Hoelzer R. 1991. Transport of amino acids via xylem and phloem in detached wheat shoots. In: Bonnemain JL, Delrot S, Lucas WJ, Dainty J, eds. Recent advances in phloem transport and assimilate compartmentation. Ouest Editions, 91-5.

Feller U, Keist M. 1986. Senescence and nitrogen metabolism in annual plants. In: Lambers $\mathrm{H}$, Neeteson JJ, Stulen I, eds. Fundamental, ecological and agricultural aspects of nitrogen metabolism in higher plants. Dordrecht: Martinus Nijhoff Publishers, 219-34.

Feller UK, Soong T-ST, Hageman RH. 1977. Leaf proteolytic activities and senescence during grain development of fieldgrown corn (Zea mays L.). Plant Physiology 59, $290-4$.

Fischer A, Feller U. 1993. The pattern of proteins and of peptide hydrolase activities in shoots of field-grown winter wheat during the cold season. Agronomie 13, 293-9.

Fischer A, Salgó A, Hildbrand M, Feller U. 1992. Co-operative protection of glucose-6-phosphate dehydrogenase by ligands in extracts from wheat grains. Biochemie und Physiologie der Pflanzen 188, 295-303.

Fröhlich V, Feller U. 1991. Effect of phloem interruption on senescence and protein remobilization in the flag leaf of field- grown wheat. Biochemie und Physiologie der Pflanzen 187, 139-47.

Fröhlich V, Feller U. 1992. Effect of phloem interruption on endopeptidase and aminopeptidase activities in flag leaves of field-grown wheat. Biochemie und Physiologie der Pflanzen 188, $13-21$.

Hilditch PJ, Thomas H, Thomas BJ, Rogers LJ. 1989. Leaf senescence in a non-yellowing mutant of Festuca pratensis: Proteins of photosystem II. Planta 177, 265-72.

Höpfner M, Reifferscheid G, Wild A. 1988. Molecular composition of glutamine synthetase of Sinapis alba L. Zeitschrift fär Naturforschung 43c, 194-8.

Ida S. 1987. Immunological comparisons of ferredoxin-nitrite reductases from higher plants. Plant Science 49, 111-16.

Krapp A, Quick WP, Stitt M. 1991. Ribulose-1,5-bisphosphate carboxylase-oxygenase, other Calvin-cycle enzymes, and chlorophyll decrease when glucose is supplied to mature spinach leaves via the transpiration stream. Planta 186, 58-69.

Kurlandsky SB, Hilburger AC, Levy HR. 1988. Glucose-6-phosphate dehydrogenase from Leuconostoc mesenteroides: Ligand-induced conformational changes. Archives of Biochemistry and Biophysics 264, 93-102.

Laemmli UK. 1970. Cleavage of structural proteins during the assembly of the head of bacteriophage T4. Nature 227, 680-5.

Laskey RA. 1984. Radioisotope detection by fuorography and intensifying screens. Amersham International plc.

Malik NSA. 1983. Senescence in detached oat leaves. Il. Identification and changes in the activity levels of aminopeptidases. Plant and Cell Physiology 24, 1011-16.

Marquez AJ, Avila C, Forde BG, Wallsgrove RM. 1988. Ferredoxin-glutamate synthase from barley leaves: Rapid purification and partial characterization. Plant Physiology and Biochemistry 26, 645-51.

Martin C, Thimann KV. 1972. Role of protein synthesis in the senescence of leaves. II. The influence of amino acids on senescence. Plant Physiology 50, 432-7.

Mitsuhashi W, Feller U. 1992. Effects of light and external solutes on the catabolism of nuclear-encoded stromal proteins in intact chloroplasts isolated from pea leaves. Plant Physiology 100, 2100-5.

Okada K, Inoue Y, Satoh K, Katoh S. 1992. Effects of light on degradation of chlorophyll and proteins during senescence of detached rice leaves. Plant and Cell Physiology 33, 1183-91.

Peeters KMU, van Laere AJ. 1992. Ammonium and amino acid metabolism in excised leaves of wheat (Triticum aestivum) senescing in the dark. Physiologia Plantarum 84, 243-9.

Salgo A, Feller U. 1987. Rapid micro methods for the determination of exo- and endopeptidase activities in plant extracts. Microchemical Journal 35, 13-21.

Schenk D, Feller U. 1990. Effect of phloem interruption on leaf senescence and nutrient redistribution in wheat (Triticum aestivum). In: van Beusichem $\mathrm{ML}$, ed. Plant nutritionphysiology and applications. Dordrecht: Kluwer Academic Publishers, 121-5.

Shibaoka H, Thimann KV. 1970. Antagonisms between kinetin and amino acids. Experiments on the mode of action of cytokinins. Plant Physiology 46, 212-20.

Strain HH, Cope BT, Svec WA. 1971. Analytical procedures for the identification, estimation and investigation of the chlorophylls. In: Sanpietro A, ed. Methods in enzymology 23, New York: Academic Press Inc., 452-87.

Thimann KV, Tetley RR, Van Thanh T. 1974. The metabolism of oat leaves during senescence. II. Senescence in leaves attached to the plant. Plant Physiology 54, 859-62. 
Thomas H. 1978. Enzymes of nitrogen mobilization in detached leaves of Lolium temulentum during senescence. Planta 142, 161-9.

Tijssen P. 1985. Practice and theory of enzyme immunoassays. Amsterdam: Elsevier Science Publishers.

Weidhase RA, Kramell H-M, Lehmann J, Liebisch H-W, Lerbs W, Parthier B. 1987a. Methyljasmonate-induced changes in the polypeptide pattern of senescing barley leaf segments. Plant Science 51, 177-86.

Weidhase RA, Lehmann J, Kramell H, Sembdner G, Parthier B. 1987b. Degradation of ribulose-1,5-bisphosphate carboxylase and chlorophyll in senescing barley leaf segments triggered by jasmonic acid methylester, and counteraction by cytokinin. Physiologia Plantarum 69, 161-6. 